\title{
Role of Silicon in Mediating Phosphorus Imbalance in Plants
}

\author{
An Yong $\mathrm{Hu}{ }^{1}$, Shu Nan Xu ${ }^{1}$, Dong Ni Qin ${ }^{1}$, Wen $\mathrm{Li}^{1}$ and Xue Qiang Zhao ${ }^{2,3, * \mathbb{C}}$ \\ 1 School of Geographical Science, Nantong University, Nantong 226019, China; ayhu2018@ntu.edu.cn (A.Y.H.); \\ 1822011014@stmail.ntu.edu.cn (S.N.X.); 1822061004@stmail.ntu.edu.cn (D.N.Q.); \\ 1822011015@stmail.ntu.edu.cn (W.L.) \\ 2 State Key Laboratory of Soil and Sustainable Agriculture, Institute of Soil Science, \\ Chinese Academy of Sciences, Nanjing 210008, China \\ 3 University of Chinese Academy of Sciences, Beijing 100049, China \\ * Correspondence: xqzhao@issas.ac.cn
}

check for updates

Citation: Hu, A.Y.; Xu, S.N.; Qin, D.N.; Li, W.; Zhao, X.Q. Role of Silicon in Mediating Phosphorus Imbalance in Plants. Plants 2021, 10, 51. https: / / doi. org/10.3390/plants10010051

Received: 27 November 2020 Accepted: 20 December 2020 Published: 29 December 2020

Publisher's Note: MDPI stays neutral with regard to jurisdictional claims in published maps and institutional affiliations.

Copyright: $\odot 2020$ by the authors. Licensee MDPI, Basel, Switzerland. This article is an open access article distributed under the terms and conditions of the Creative Commons Attribution (CC BY) license (https: / / creativecommons.org/ licenses/by/4.0/).

\begin{abstract}
The soil bioavailability of phosphorus (P) is often low because of its poor solubility, strong sorption and slow diffusion in most soils; however, stress due to excess soil $\mathrm{P}$ can occur in greenhouse production systems subjected to high levels of $\mathrm{P}$ fertilizer. Silicon (Si) is a beneficial element that can alleviate multiple biotic and abiotic stresses. Although numerous studies have investigated the effects of Si on P nutrition, a comprehensive review has not been published. Accordingly, here we review: (1) the Si uptake, transport and accumulation in various plant species; (2) the roles of phosphate transporters in $\mathrm{P}$ acquisition, mobilization, re-utilization and homeostasis; (3) the beneficial role of Si in improving P nutrition under P deficiency; and (4) the regulatory function of Si in decreasing $P$ uptake under excess P. The results of the reviewed studies suggest the important role of $\mathrm{Si}$ in mediating $\mathrm{P}$ imbalance in plants. We also present a schematic model to explain underlying mechanisms responsible for the beneficial impact of $\mathrm{Si}$ on plant adaption to P-imbalance stress. Finally, we highlight the importance of future investigations aimed at revealing the role of $\mathrm{Si}$ in regulating $\mathrm{P}$ imbalance in plants, both at deeper molecular and broader field levels.
\end{abstract}

Keywords: silicon; silicon transporter; phosphorus transporter; phosphorus imbalance; phosphorus deficiency; excess phosphorus

\section{Introduction}

Silicon ( $\mathrm{Si}$ ) is the second most abundant element in the Earth's crust, and its content within plants ranges from $0.1 \%$ to $10 \%$ depending on species. Although still not proven to be a plant-essential element, $\mathrm{Si}$ is widely recognized as a beneficial factor for plant growth and development. Si can alleviate biotic stresses, such as plant pathogens and insect pests, and abiotic stresses, such as drought, heat, cold, lodging, salinity, ultraviolet radiation, metal toxicity and nutrient imbalance [1]. Si can strengthen plant resistance to abiotic and biotic stresses via physical and physiological biochemical mechanisms. Recently, several authors have systematically reviewed research progress on the elucidation of mechanisms of Si-mediated alleviation of biotic and abiotic stresses in plants [2-7]. In these reviews, however, the beneficial effects of Si on nutrient imbalance have received relatively little attention. Because of increasing deficiencies or excesses of some essential elements in soils worldwide, the importance of Si in mitigating nutrient imbalance has gradually attracted much attention.

Phosphorus $(\mathrm{P})$ is a key element that greatly influences plant growth and productivity. Available $\mathrm{P}$ is very low in soils for two reasons: $\mathrm{P}$ fixation into organic forms, and binding or adsorption of $\mathrm{P}$ either by aluminum and iron $(\mathrm{Fe})$ oxides or calcium minerals, depending on soil $\mathrm{pH}$ [8]. Critical strategies for improving crop performance in low-P soils are the improvement of $\mathrm{P}$ acquisition efficiency by enhancing soil $\mathrm{P}$ availability and the enhancement of $\mathrm{P}$ utilization efficiency in inner plant organs. Excess-P stress is also observed in some greenhouse soils subjected to heavy application of $\mathrm{P}$ fertilizer or in 
hydroponic culture where a high P concentration is supplied [9]. The beneficial effect of $\mathrm{Si}$ on P deficiency or excess stress has been reported for a number of plant species [10-25]. To the best of our knowledge, however, no review has discussed the roles and mechanisms of $\mathrm{Si}$ in alleviating P-imbalance stress in plants. In this review, therefore, we focus on the roles of $\mathrm{Si}$ in mitigating P-deficiency or excess-P stress. We also discuss the mechanisms underlying Si enhancement of plant tolerance to P-imbalance stress.

\section{Silicon (Si) Absorption, Transport and Accumulation in Higher Plants}

All plants contain Si [26]. In some plants, termed Si-accumulator plants, concentrations of Si may be almost as high as those of macro-elements. The leaf is the organ with the highest $\mathrm{Si}$ accumulation, with Si generally accounting for more than $1.5 \%$ of leaf dry weight in Si-accumulator plants. $\mathrm{Si}$ is taken up and translocated by plants in the form of uncharged silicic acid $\left(\mathrm{H}_{4} \mathrm{SiO}_{4}\right)$, which is ultimately irreversibly precipitated as amorphous silica in cell walls and extracellular spaces by transpirational flow. The Si content of various plant species differs depending on their $\mathrm{Si}$ absorption capabilities and Si loading capacities from roots to xylem [27].

Although the cytoplasmic membrane of plant roots may provide a channel for the absorption of silicic acid by non-ionic diffusion, the permeability coefficient of silicic acid through the plasma membrane is only $10^{-10} \mathrm{~m} \cdot \mathrm{s}^{-1}$ [28]. This proposed route is, therefore, not consistent with the characteristics of some Si-accumulating plants, especially graminaceous ones [29]. Absorption of Si by plants and its transport to the xylem involve both passive and active uptake processes [30]. Si uptake by plants is significantly inhibited by treatment with metabolic inhibitors (2,4-dinitrophenol and potassium cyanide) or low temperature stress, thus demonstrating that plants can actively absorb and transport Si [29-31]. Plant roots are able to take up Si from an external medium and transfer it to cortical cells via a low-affinity silicic acid transporter with a $\mathrm{Km}$ value of $0.15 \mathrm{mM}$. In one kinetic study, differences in Si uptake by rice (Oryza sativa), cucumber (Cucumis sativus) and tomato (Solanum lycopersicum) were found to be correlated with the abundance of Si transporters on the root plasma membrane, which was highest and lowest in rice and tomato, respectively [30].

The identification of two Si transporter genes (OsLsi1 and OsLsi2) in rice was a landmark discovery that accelerated the development of the field of plant Si research [32,33]. OsLsi1 belongs to the nodulin 26-like intrinsic protein (NIP) subfamily of aquaporins, which is responsible for Si uptake from soil into root cells. In rice, OsLsi1 is an influx Si transporter located on the distal side of both exodermis and endodermis in roots. OsLsi2 is a putative anion and efflux transporter located on the proximal side of endodermis and exodermis in the root plasma membrane. According to a mathematical model based on a simple diffusion equation, this characteristic cellular localization pattern explains the high Si uptake capacity of rice [34]. A number of genes involved in Si uptake and distribution (Lsi1, Lsi2, Lsi3 and Lsi6) have now been identified and functionally validated in numerous plant species, both monocots, such as rice, maize (Zea mays) and barley (Hordeum vulgare), and dicots, such as pumpkin (Cucurbita moschata), cucumber, tomato and horsetail (Equisetum arvense) (Table 1) [32,33,35-47]. Depending on the plant species, these genes are expressed in roots, shoots or both organs (Table 1). The tissue and cellular locations of these genes, which differ among plant species, determine the different roles of Si transporters in plant $\mathrm{Si}$ uptake, transport and accumulation. 
Table 1. Genes involved in Si transport in plants.

\begin{tabular}{|c|c|c|c|c|c|}
\hline Plant Species & Gene Name & Function & Spatial Expression & $\begin{array}{c}\text { Transcriptional } \\
\text { Regulation by Si Supply }\end{array}$ & References \\
\hline \multirow{4}{*}{ Oryza sativa } & OsLsi1 & $\begin{array}{l}\text { Si influx } \\
\text { transporter }\end{array}$ & $\begin{array}{l}\text { Distal side of both } \\
\text { exodermis and } \\
\text { endodermis in roots }\end{array}$ & Downregulated & {$[32]$} \\
\hline & OsLsi2 & $\begin{array}{c}\text { Si efflux } \\
\text { transporter }\end{array}$ & $\begin{array}{l}\text { Proximal side of } \\
\text { both exodermis and } \\
\text { endodermis in roots; } \\
\text { bundle sheath } \\
\text { cell layer } \\
\text { around enlarged } \\
\text { vascular bundles }\end{array}$ & Downregulated & {$[33]$} \\
\hline & OsLsi3 & $\begin{array}{l}\text { Si efflux } \\
\text { transporter }\end{array}$ & $\begin{array}{l}\text { Parenchyma tissues } \\
\text { between enlarged } \\
\text { vascular bundles } \\
\text { and diffuse } \\
\text { vascular bundles }\end{array}$ & Unknown & {$[35]$} \\
\hline & OsLsi6 & $\begin{array}{l}\text { Si influx } \\
\text { transporter }\end{array}$ & $\begin{array}{l}\text { Xylem transfer cells } \\
\text { located at the outer } \\
\text { boundary region of } \\
\text { enlarged large } \\
\text { vascular bundles in } \\
\text { node I }\end{array}$ & Unknown & [35-37] \\
\hline \multirow[t]{3}{*}{ Zea mays } & ZmLsi1 & $\begin{array}{l}\text { Si influx } \\
\text { transporter }\end{array}$ & $\begin{array}{l}\text { Plasma membrane of } \\
\text { the distal side of root } \\
\text { epidermal and } \\
\text { hypodermal cells in } \\
\text { seminal and crown } \\
\text { roots; cortex cells in } \\
\text { lateral roots }\end{array}$ & Unaffected & {$[38]$} \\
\hline & ZmLsi2 & $\begin{array}{c}\text { Si efflux } \\
\text { transporter }\end{array}$ & $\begin{array}{l}\text { Endodermis with no } \\
\text { polarity in roots }\end{array}$ & Downregulated & [39] \\
\hline & ZmLsi6 & $\begin{array}{l}\text { Si transporter for } \\
\text { xylem unloading }\end{array}$ & $\begin{array}{l}\text { Xylem parenchyma } \\
\text { cells closed to vessels } \\
\text { in both leaf sheaths } \\
\text { and leaf blades }\end{array}$ & Unaffected & [38] \\
\hline \multirow{3}{*}{ Hordeum vulgare } & HvLsi1 & $\begin{array}{l}\text { Si influx } \\
\text { transporter }\end{array}$ & $\begin{array}{l}\text { Plasma membrane } \\
\text { on the distal side of } \\
\text { epidermal and } \\
\text { cortical cells; plasma } \\
\text { membrane of } \\
\text { hypodermal cells in } \\
\text { lateral roots }\end{array}$ & Unaffected & [40] \\
\hline & HvLsi2 & $\begin{array}{c}\text { Si efflux } \\
\text { transporter }\end{array}$ & $\begin{array}{l}\text { Endodermis with no } \\
\text { polarity in roots }\end{array}$ & Downregulated & [39] \\
\hline & HvLsi6 & $\begin{array}{l}\text { Si uptake in root } \\
\text { tips; xylem } \\
\text { unloading in leaf } \\
\text { blades and } \\
\text { sheaths; } \\
\text { intervascular } \\
\text { transfer in nodes }\end{array}$ & $\begin{array}{l}\text { Epidermis and } \\
\text { cortex cells of tips; } \\
\text { parenchyma cells of } \\
\text { vascular bundles in } \\
\text { leaf blades and } \\
\text { sheaths; transfer } \\
\text { cells surrounding } \\
\text { enlarged vascular } \\
\text { bundles adjacent } \\
\text { to numerous } \\
\text { xylem vessels }\end{array}$ & Unaffected & [41] \\
\hline
\end{tabular}


Table 1. Cont.

\begin{tabular}{|c|c|c|c|c|c|}
\hline Plant Species & Gene Name & Function & Spatial Expression & $\begin{array}{c}\text { Transcriptional } \\
\text { Regulation by Si Supply }\end{array}$ & References \\
\hline \multirow{2}{*}{$\begin{array}{l}\text { Cucurbita } \\
\text { moschata }\end{array}$} & CmLsi1 & $\begin{array}{l}\text { Si influx } \\
\text { transporter }\end{array}$ & $\begin{array}{l}\text { Plasma membrane of } \\
\text { all cells in roots }\end{array}$ & Unknown & [43] \\
\hline & $\begin{array}{l}\text { CmLsi2-1; } \\
\text { CmLsi2-2 }\end{array}$ & $\begin{array}{l}\text { Si efflux } \\
\text { transporter }\end{array}$ & Roots and shoots & Unknown & {$[42]$} \\
\hline \multirow[t]{2}{*}{ Cucumis satious } & CsLsi1 & $\begin{array}{l}\text { Si influx } \\
\text { transporter }\end{array}$ & $\begin{array}{l}\text { Distal side of } \\
\text { endodermis and } \\
\text { cortical cells in root } \\
\text { tips as well as root } \\
\text { hairs near root tips }\end{array}$ & Downregulated & {$[44]$} \\
\hline & CsLsi2 & $\begin{array}{l}\text { Si efflux } \\
\text { transporter }\end{array}$ & $\begin{array}{l}\text { Endodermal cells of } \\
\text { roots without } \\
\text { polar distribution }\end{array}$ & Unknown & {$[45]$} \\
\hline $\begin{array}{c}\text { Solanum } \\
\text { lycopersicum }\end{array}$ & SlLsi1 & $\begin{array}{l}\text { Si influx } \\
\text { transporter }\end{array}$ & $\begin{array}{c}\text { Plasma membrane of } \\
\text { both root tips and } \\
\text { basal regions } \\
\text { without polarity }\end{array}$ & Unaffected & [46] \\
\hline Equisetum arvense & $\begin{array}{l}\text { EaLsi2-1 } \\
\text { EaLsi2-2 }\end{array}$ & $\begin{array}{l}\text { Si efflux } \\
\text { transporter }\end{array}$ & Roots and shoots & Unknown & [47] \\
\hline
\end{tabular}

\section{Phosphorus (P) Uptake and Utilization by Plants}

One of the most essential mineral elements, $\mathrm{P}$ is not only a component of many important compounds in plants, such as nucleic acids, proteins and phospholipids, but also plays an important role in photosynthesis, respiration and many enzymatic reactions [48]. $\mathrm{P}$ homeostasis in plants is, therefore, indispensable for normal physiological and biochemical functioning, but most $\mathrm{P}$ in soils is biologically unavailable because of its poor solubility, strong sorption and slow diffusion [49]. Approximately $30 \%$ of the world's agricultural soils are estimated to be $P$ deficient [50]. To ensure crop productivity and quality, farmers often increase the amount of P fertilizer applied to P-deficient soils. Unfortunately, the P use efficiency of applied P fertilizer is less than $20 \%$, with the residual P easily immobilized in soil or flowing into surface water through runoff [51]. In addition, rock $\mathrm{P}$, a non-renewable resource and the main source of $P$ fertilizer, is estimated to become exhausted within the next 50-100 years [52].

P often exists in soil in two chemical forms: organic and inorganic (orthophosphate, $\mathrm{Pi}$ ). Pi acquisition, utilization and homeostasis depend on complicated transport processes mediated by Pi transporters belonging to five phosphate transporter (PHT) families: PHT1 to PHT5 [53-56]. Plant PHT1 family proteins, whose role in P uptake, mobilization and re-utilization has been widely studied, belong to a major facilitator superfamily (MFS). $P$ transport characteristics and kinetic parameters $(\mathrm{Km})$ differ significantly among PHT1 family members. Many PHT1 family members have been identified in higher plants, including Arabidopsis (Arabidopsis thaliana), rice, wheat (Triticum aestivum), maize, barley, soybean (Glycine max), sorghum (Sorghum bicolor), tomato and potato (Solanum tuberosum) [57]. Most PHT1 family genes are induced by Pi starvation and expressed mainly in plant roots, with the expression of a few family members also detectable in other plant organs [53,58-60]. Some MYB and WRKY transcriptional factors and ZAT6 can bind to various cis-elements, such as MYCS, P1BS and W-box elements, in the promoter region of plant PHT1 family genes [61-65] to regulate PHT1 gene expression. PHT1 family genes are also affected by arbuscular mycorrhiza $[55,66,67]$. This post-transcriptional gene regulation is also crucial for proper plant responsiveness to Pi. PHF1 proteins, SPX domain-containing proteins, microRNAs, and phosphorylation/dephosphorylation proteins are also involved in the 
post-transcriptional regulation and signal transduction of PHT1 family genes [68-74], as are plant hormones such as auxin, ethylene and cytokinin [75-78].

PHT1 proteins, which generally function in the acquisition of Pi from soil, have received far more attention than other PHT family genes. PHT2, PHT3, PHT4 and PHT5 family members, which play vital roles in maintaining Pi distribution and homeostasis in plants, are localized in plastids [79,80], mitochondria [54], the plastid envelope or the Golgi apparatus [81] and vacuolar membranes [82], respectively. The chloroplast envelopelocalized protein PHT2 is responsible for Pi translocation into leaves and Pi starvation responses [79,83]. PHT3 family members, which are plant mitochondrial Pi transporters, are involved in Pi exchange between the cytoplasm and the mitochondrial matrix via the $\mathrm{Pi} / \mathrm{H}^{+}$ symport or Pi/ $\mathrm{OH}^{-}$antiport [84,85]. The plastid and Golgi apparatus-located PHT4 genes play important roles in various biological processes, including Pi translocation in plastids and the Golgi apparatus [81,86], carbon metabolism [87,88], pathogen resistance [89], and salt tolerance [90]. SYG1/PHO81/XPR1-MFS (SPX-MFS) proteins, which constitute the PHT5 family, function in Pi sequestration in vacuoles and the transport of Pi across the tonoplast in plants [82,91].

\section{Mechanisms of Si Alleviation of P-Deficiency Stress in Plants}

The first evidence of Si-alleviated P deficiency was obtained from a long-term field experiment conducted at the Rothamsted Experimental Station. In that experiment, which compared barley yields in two fields not subjected to $\mathrm{P}$ fertilizer application, the yield of barley fertilized with $\mathrm{Si}$ was higher than that of a field without $\mathrm{Si}$ amendment [18]. The beneficial effect of Si on P-deficiency stress has been subsequently reported in several graminaceous species, such as wheat, rice and maize, under soil cultivation as well as hydroponic conditions (Table 2). It is known that large amounts of P exist in soils bound in unavailable form $[92,93]$. The effect of Si on P deficiency was initially thought to be associated with the enhancement of $P$ availability in soil. A significantly positive correlation existed between Si availabilities and P mobilization in 143 representative Artic soils [94]. Furthermore, exogenous $\mathrm{Si}$ also was proved to contribute to the increased $\mathrm{P}$ activization from Fe-P phases on mineral surfaces [94,95]. Many studies have shown that the increased soil $\mathrm{P}$ availability under high $\mathrm{Si}$ can be explained by Si competition with $\mathrm{P}$ for binding at the surface of soil minerals resulting in P mobilization [96-102]. Several studies suggest that the competitive ability of $\mathrm{Si}$ against $\mathrm{P}$ may be $\mathrm{pH}$-dependent [21,103-105]. The effect of Si on soil P mobilization may depend on Si fertilizer form, Si level, soil mineralogy and plant $P$ uptake.

Table 2. Summary of effects of silicon (Si) on phosphorus $(\mathrm{P})$ content and plant growth: $(-)$ inhibition, $(+)$ stimulation, and (0) no change.

\begin{tabular}{|c|c|c|c|c|c|c|c|}
\hline Taxon & Si Form & P Level & $\begin{array}{c}\text { Experimental } \\
\text { Conditions }\end{array}$ & $\begin{array}{c}\mathrm{pH} \text { of } \\
\text { Experimental } \\
\text { Medium }\end{array}$ & $\begin{array}{l}\text { Effects on } \\
\text { Shoot P } \\
\text { Content }\end{array}$ & $\begin{array}{l}\text { Effects on } \\
\text { Plant } \\
\text { Growth? }\end{array}$ & References \\
\hline $\begin{array}{l}\text { Glycine max; } \\
\text { Fragaria } \\
\text { ananassa; } \\
\text { Solanum } \\
\text { lycopersicum }\end{array}$ & Silicic acid & $\begin{array}{l}0.58 \mathrm{mM} ; \\
0.23 \mathrm{mM} ; \\
2.3 \mathrm{mM} ;\end{array}$ & Hydroponic & 5.5 & Decreased & + & [10-12] \\
\hline Oryza sativa & Silicic acid & $1.4-700 \mu \mathrm{M}$ & Hydroponic & 5.5 & $\begin{array}{c}\text { No effects } \\
\text { under low P } \\
\text { ( } \leq 14 \text { ppm), but } \\
\text { decreased at } \\
\text { higher P levels }\end{array}$ & + & {$[13,14]$} \\
\hline
\end{tabular}


Table 2. Cont.

\begin{tabular}{|c|c|c|c|c|c|c|c|}
\hline Taxon & Si Form & P Level & $\begin{array}{l}\text { Experimental } \\
\text { Conditions }\end{array}$ & $\begin{array}{c}\mathrm{pH} \text { of } \\
\text { Experimental } \\
\text { Medium }\end{array}$ & $\begin{array}{l}\text { Effects on } \\
\text { Shoot } P \\
\text { Content }\end{array}$ & $\begin{array}{l}\text { Effects on } \\
\text { Plant } \\
\text { Growth? }\end{array}$ & References \\
\hline $\begin{array}{l}\text { Cucumis } \\
\text { satious }\end{array}$ & Silicic acid & $0.05-1.2 \mathrm{mM}$ & Hydroponic & 5.5 & $\begin{array}{c}\text { No effects } \\
\text { under low P } \\
(0.05 \mathrm{mM}) \text {, but } \\
\text { decreased at } \\
\text { higher P levels }\end{array}$ & + & [15] \\
\hline Oryza sativa & Silicic acid & $90-210 \mu \mathrm{M}$ & Hydroponic & 5.5 & Decreased & + & [16] \\
\hline $\begin{array}{c}\text { Solanum } \\
\text { lycopersicum }\end{array}$ & $\begin{array}{l}\text { Potassium } \\
\text { silicate }\end{array}$ & $0.44-0.66 \mathrm{mM}$ & Hydroponic & $5.8-6.0$ & Increased & + & [17] \\
\hline $\begin{array}{l}\text { Hordeum } \\
\text { vulgare }\end{array}$ & $\begin{array}{l}\text { Sodium } \\
\text { silicate }\end{array}$ & $\begin{array}{c}\text { No P } \\
\text { addition }\end{array}$ & Field & Unknown & $\begin{array}{l}\text { Decreased } \\
\text { slightly }\end{array}$ & + & [18] \\
\hline Oryza sativa & Silicic acid & $\begin{array}{c}\text { No P } \\
\text { addition }\end{array}$ & Soil culture & 4.5 & No effects & + & [19] \\
\hline Oryza sativa & $\begin{array}{l}\text { Sodium } \\
\text { silicate }\end{array}$ & $\begin{array}{c}\text { No P } \\
\text { addition }\end{array}$ & Soil culture & 4.5 & No effects & + & [20] \\
\hline Zea mays & $\begin{array}{l}\text { Calcium } \\
\text { silicate }\end{array}$ & $\begin{array}{l}0-0.3 \text { g per } \\
1.5 \mathrm{~kg} \text { soil }\end{array}$ & Soil culture & 5.3 & Increased & + & [21] \\
\hline Oryza sativa & $\begin{array}{c}\text { Diatomaceous } \\
\text { earth }\end{array}$ & $\begin{array}{c}25- \\
50 \mathrm{~kg} \mathrm{P} \mathrm{ha}^{-1}\end{array}$ & Field & 7.4 & Increased & + & [22] \\
\hline Oryza sativa & $\begin{array}{c}\text { Wollastonite, } \\
\text { slag and } \\
\text { foliar } \mathrm{Si} \\
\text { solution }\end{array}$ & $\begin{array}{l}4.5 \text { ton } \mathrm{ha}^{-1} \\
\text { and } \\
0-80 \mathrm{mg} \mathrm{L}^{-1}\end{array}$ & Soil culture & 6.1 & No effects & 0 or - & [23] \\
\hline $\begin{array}{l}\text { Triticum } \\
\text { aestioum }\end{array}$ & $\begin{array}{l}\text { Sodium } \\
\text { silicate }\end{array}$ & $\begin{array}{c}\text { No P } \\
\text { addition }\end{array}$ & Soil culture & 4.0 & Increased & + & [24] \\
\hline $\begin{array}{l}\text { Solanum } \\
\text { tuberosum }\end{array}$ & $\begin{array}{l}\text { Powder } \\
\text { FertiSilica }\end{array}$ & 10-200 ppm & Soil culture & 4.5 & No effects & 0 & [25] \\
\hline
\end{tabular}

$\mathrm{Si}$ is commonly applied as calcium or sodium silicate, both of which increase soil $\mathrm{pH}$. In acidic soils, aluminum (Al) toxicity is the most important factor limiting crop growth and production. At soil $\mathrm{pH}$ values at or below $\mathrm{pH} 5, \mathrm{Al}$ ions are solubilized into the soil solution and dramatically inhibit root growth and function, in turn severely impairing water and nutrient acquisition by roots and, thereby, leading to a significant reduction in crop yields $[8,106,107]$. An increase in soil $\mathrm{pH}$ due to $\mathrm{Si}$ application can effectively improve the growth condition of plant roots suffering from $\mathrm{Al}$ toxicity [24], thus resulting in increased transpiration and, therefore, greater $\mathrm{P}$ uptake and utilization [21]. Furthermore, high soil $\mathrm{pH}$, within a certain range, can facilitate soil $\mathrm{P}$ activization and plant $\mathrm{P}$ uptake [108].

Plants have evolved diverse strategies to cope with P deficiency. One effective strategy to counteract P-deficiency stress is the secretion of organic acid anions (e.g., malate, citrate and oxalate) by plant roots [109]. Current evidence indicates that $\mathrm{Si}$ application strongly promotes the exudation of both malate and citrate by roots, with the amounts of these anions released by roots always higher than in other tested treatments [24]. The highest efflux of malate and citrate in response to P deficiency occurs following Si treatment. Furthermore, Si has been reported to upregulate the expressions of Pi transporter genes (TaPHT1;1 and TaPHT1;2) in wheat roots at low P [24]. Despite these findings, the mechanisms underlying Si modulation of Pi transporter gene expression in roots require further study. At low $P$ levels, in fact, the greatest beneficial effect of Si on plant growth, improvement of internal $\mathrm{P}$ use efficiency, occurs indirectly via a decrease in Fe and manganese (Mn) uptake [14]. Si-decreased Mn accumulation in shoots is due to the decrease of $\mathrm{Mn}$ translocation from roots to shoots by the formation of Mn-Si complex in root cells, and down-regulating the 
expression of Mn transporter gene [110]. Given that P usually has a high affinity to metals such as Fe and Mn [9], the internal availability of P in plants may be affected by levels of $\mathrm{Mn}, \mathrm{Fe}$ and other metals when the P concentration is low.

\section{Mechanisms of Si-Based Alleviation of Excess-P Stress in Plants}

Excess-P stress rarely occurs in natural soils. In greenhouse production systems, however, famers apply high levels of $\mathrm{P}$ fertilizer, which results in large amounts of $\mathrm{P}$ accumulated in the soil [111]. Soil Olsen-P, an important indicator of soil $\mathrm{P}$ supply ability and the risk of soil $\mathrm{P}$ runoff and leaching into the environment, has reached as high as $200 \mathrm{mg} \mathrm{P} \mathrm{kg}^{-1}$ in greenhouse systems (compared with the critical value of 46.0-58.0 mg P kg-1 in vegetable field soils) [112-114]. Although accumulated P is required for metabolism and storage in plants, high $\mathrm{P}$ concentrations inhibit enzymatic reactions, create abnormal osmotic pressure, and decrease essential metal element availability in cells [115]. For example, excess P application has been shown to reduce zinc ( $\mathrm{Zn})$ uptake and bioavailability [116-119]. Recent studies suggest that the Zn concentration in aerial parts of plants is negatively related to soil-available $P$ in both calcareous and acid soils, while a high $\mathrm{P}$ concentration in soil has a strong antagonistic effect on $\mathrm{Zn}$ accumulation in plants $[120,121]$. In plants, typical symptoms of P-induced Zn deficiency are leaf chlorosis and necrosis [122]. Furthermore, low Zn levels in plants that are important nutritional sources of this element, such as cereal grains and vegetables, may lead to inadequate Zn intake in humans.

In several plant species, $\mathrm{Si}$ alleviation of excess $\mathrm{P}$ damage has been attributed to a decrease in P uptake (Table 2) that reduced the concentration and accumulation of inorganic $\mathrm{P}$ in plants. In one hydroponic experiment, Si significantly decreased $\mathrm{P}$ uptake by rice under high $P$ levels, with the amount of inorganic $P$ in shoots almost half that of shoots cultivated without supplemental Si [14]. Si has been found to decrease P uptake in rice as well as some Si non-accumulating plants, such as tomato, soybean and strawberry (Fragaria vesca) [27]. Furthermore, application of Si to cucumber, a moderate Si accumulator, has also been found to alleviate symptoms of toxicity induced by $\mathrm{P}$ excess, resulting in a marked decrease in leaf $\mathrm{P}$ and an increase in the proportion of water-extractable $\mathrm{Zn}$ [15].

One possible explanation for the aforementioned observations is that Si deposition in endodermal cells of plant roots may contribute to decreased P uptake and alleviation of excess-P stress. This effect has been attributed to the formation of apoplastic barriers to $\mathrm{P}$ permeability across roots caused by $\mathrm{Si}$ deposition in roots, which decreases excessive uptake of P $[9,123]$. Another explanation is that the formation of a cuticle-silica double layer due to Si deposition in leaves reduces the plant transpiration rate. Transpiration is negatively correlated with the Si content of aerial parts of rice, and the rice transpiration rate can be reduced by $20-30 \%$ when the $\mathrm{SiO}_{2}$ content of shoots exceeds $10 \%$ of the dry matter weight [104]. A positive correlation exists between plant leaf P content and transpiration rate [124]. Except for several Si-accumulator plants, however, most plant species accumulate little $\mathrm{Si}$ in their organs. In addition to the physical barrier function of Si deposition in roots or leaves, Si may therefore participate in the regulation of plant responses to excess-P stress in other ways.

A number of studies have suggested that Si improves the growth of plants under abiotic stress by regulating the expressions of genes directly associated with the uptake and translocation of stress factors. We recently investigated the effect of Si on P uptake and accumulation under high $\mathrm{P}$ concentrations in both relatively long- and short-term experiments. We found that Si decreased both $\mathrm{P}$ uptake and accumulation in rice by downregulating the $\mathrm{P}$ transporter gene OsPHT1;6 in roots [16]. A split-root experiment further indicated that OsPHT1;6 expression was decreased by Si accumulation in shoots, resulting in decreased Pi uptake in rice [16]. In this study, we dissected the physiological and molecular mechanisms underlying the beneficial effects of $\mathrm{Si}$ under excess-P stress using the rice mutant $l s i 1$, defective in Si uptake. Compared with the wild type, Oochikara, lsi1 accumulated a similar level of $\mathrm{Si}$ in roots but exhibited much less accumulation in 
shoots [125]. By taking advantage of this mutant, the study has proved the importance of $\mathrm{Si}$ accumulation in shoots to alleviate excess-P stress.

In cereal crops, $\mathrm{P}$ stored in seeds accounts for $60-85 \%$ of total plant $\mathrm{P}$ at maturity [126-128]. Moreover, approximately $65-85 \%$ of total $\mathrm{P}$ in grains is stored in the form of phytate [121]. Phytate, which is barely digestible by monogastric animals and humans, combines with some essential microelements, such as $\mathrm{Zn}$ and $\mathrm{Fe}$, thus greatly reducing their availability [129]. Additionally, non-digested phytate is excreted into the environment. Decreasing the total $\mathrm{P}$ and phytate content of grains is thus an important goal for solving these environmental and nutritional problems [130]. In a field experiment, we observed that wild-type plants accumulated less $\mathrm{P}$ in grains, husks and straw compared with the $\mathrm{Si}$ uptake-defective mutant lsi1 [16]. This result can be attributed to a decrease in P uptake in the wild type caused by $\mathrm{Si}$, as higher $\mathrm{Si}$ accumulation was observed in shoots of the wild type than in lsi1 [16]. This finding indicates that $\mathrm{Si}$ has an important role in reducing $\mathrm{P}$ input to maintain $\mathrm{P}$ balance and in increasing the nutritional value of primary products.

\section{Conclusions and Future Prospects}

Although not considered an essential element in higher plants, Si has been shown to have beneficial roles in the enhancement of plant resistance to various biotic and abiotic stresses, including diseases, insect pests, drought, salt, heavy metals and nutrient imbalance. Many studies have been conducted to illustrate the mechanisms of Si alleviation of Pdeficiency or excess-P stress. These investigations have collectively shown the beneficial effects of Si supplementation on P-imbalance stress in different plant species. In regard to the diversity of the Si-mediated P-imbalance stress resistance mechanisms, the abovedescribed studies in this review have demonstrated that exogenous $\mathrm{Si}$ application is able to alleviate P-deficiency stress by increasing P mobility, decreasing exchangeable $\mathrm{Al}^{3+}$ in acid soils, increasing the exudation of both malate and citrate, upregulating P transporter genes and enhancing internal P utilization by decreasing Fe and Mn uptake (Figure 1). At the same time, the positive effects of exogenous Si on excess-P stress can be attributed to the formation of apoplastic barriers arising from $\mathrm{Si}$ deposition in the cortex cells of roots and also the downregulation of $P$ transporter genes (Figure 1).

Si-mediated tolerance mechanisms against P-deficiency or excess-P stress should continue to contribute to the improvement of P-imbalance stresses in diverse crop plants. Given currently published results, however, research on the improvement of plant $P$ balance via Si has mainly focused on physiology and biochemistry, with deeper molecular regulatory mechanisms remaining to be fully revealed. Therefore, our recommendations regarding future research on $\mathrm{Si}$ alleviation of P-imbalance stresses and research prospects are as follows:

(1) With the development of multi-omics methods, such as metabolomics, ionomics, transcriptomics and proteomics, the molecular mechanisms of Si mitigation of plant biotic and abiotic stresses can be explored in depth. These investigations should provide new insights and opportunities for dissecting the underlying mechanisms of Si mediation of $\mathrm{P}$ balance in plants under P-deficiency or excess-P stress.

(2) Recent studies have demonstrated experimentally the direct effect of Si on the expressions of P transporter genes (TaPHT1;1, TaPHT1;2 and OsPHT1;6), but the associated detailed regulatory mechanisms and signaling pathways have not yet been fully determined.

(3) lsi1 is a rice mutant defective in Si uptake. Although Si accumulation in the roots of lsi1 is similar to that of the wild type, the level of Si accumulated in shoots is much lower in the mutant. This characteristic can be applied to help researchers distinguish the different roles of Si accumulation in shoots and roots in Si alleviation of P-imbalance stress. 


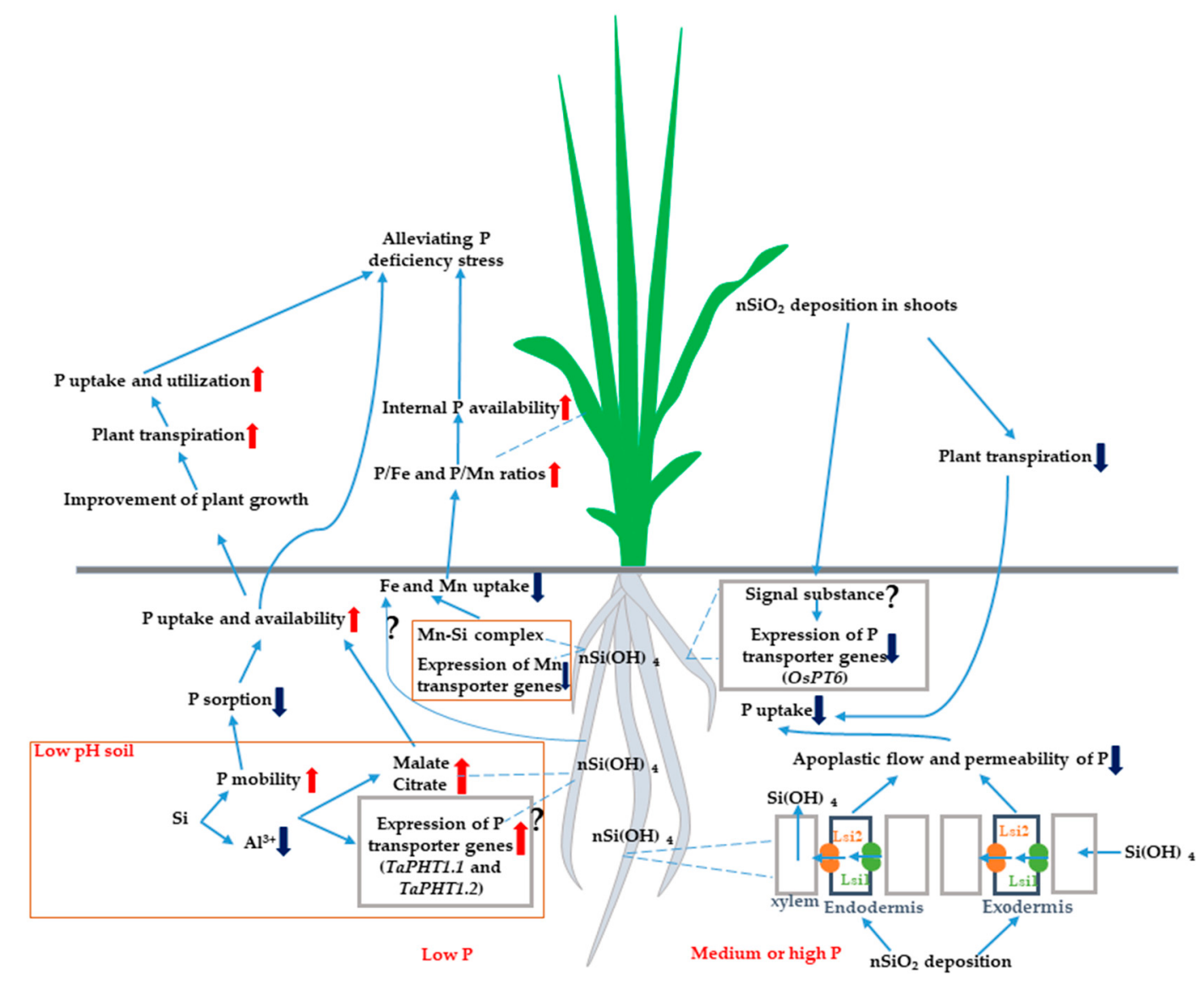

Figure 1. A schematic model for the beneficial impact of silicon on plant under P imbalance stress.

The adaptive mechanisms of plant response to P-imbalance stress are complex. The regulatory effects of Si on P-deficiency or excess-P stress may constitute a complex system involving various biochemical and physiological processes as well. Consequently, systematic studies of Si-mediated alleviation of P-imbalance stress in plants with a focus on molecular and genetic levels should provide a theoretical foundation for practical applications of $\mathrm{Si}$ to agricultural production.

Author Contributions: Conceptualization, A.Y.H. and X.Q.Z.; investigation, A.Y.H.; writing—original draft preparation, A.Y.H., S.N.X., D.N.Q. and W.L.; writing-review and editing, X.Q.Z.; funding acquisition, X.Q.Z. and A.Y.H. All authors have read and agreed to the published version of the manuscript.

Funding: This research was funded by the National Natural Science Foundation of China (No. 31672229), the Natural Science Foundation of Jiangsu Province, China (No. BK20190921), the Science Foundation of Nantong City (no. JC2019157) and the National Training Program of Innovation and Entrepreneurship for Undergraduates, China (No. 202010304061Z).

Conflicts of Interest: The authors declare no conflict of interest.

\section{References}

1. Ma, J.F.; Yamaji, N. A cooperative system of silicon transport in plants. Trends Plant Sci. 2015, 20, 435-442. [CrossRef] [PubMed]

2. Coskun, D.; Britto, D.T.; Huynh, W.Q.; Kronzucker, H.J. The role of silicon in higher plants under salinity and drought stress. Front. Plant Sci. 2016, 7, 1072. [CrossRef] [PubMed]

3. Debona, D.; Rodrigues, F.A.; Datnoff, L.E. Silicon's role in abiotic and biotic plant stresses. Annu. Rev. Phytopathol. 2017, 55, 85-107. [CrossRef] [PubMed]

4. Bhat, J.A.; Shivaraj, S.M.; Singh, P.; Navadagi, D.B.; Tripathi, D.K.; Dash, P.K.; Solanke, A.U.; Sonah, H.; Deshmukh, R. Role of silicon in mitigation of heavy metal stresses in crop plants. Plants 2019, 8, 71. [CrossRef] [PubMed] 
5. Coskun, D.; Deshmukh, R.; Sonah, H.; Menzies, J.G.; Reynolds, O.; Ma, J.F.; Kronzucker, H.J.; Bélanger, R.R. The controversies of silicon's role in plant biology. New Phytol. 2019, 221, 67-85. [CrossRef]

6. Khan, A.; Khan, A.L.; Muneer, S.; Kim, Y.H.; Al-Rawahi, A.; Al-Harrasi, A. Silicon and salinity: Cross-talk in crop mediated stress tolerance mechanisms. Front. Plant Sci. 2019, 10, 1429. [CrossRef]

7. Zhu, Y.X.; Gong, H.J.; Yin, J.L. Role of silicon in mediating salt tolerance in plants: A review. Plants 2019, 8, 147. [CrossRef]

8. Kochian, L.V.; Hoekenga, O.A.; Pineros, M.A. How do crop plants tolerate acid soils? Mechanisms of aluminum tolerance and phosphorous efficiency. Annu. Rev. Plant Biol. 2004, 55, 459-493. [CrossRef]

9. Ma, J.F. Role of silicon in enhancing the resistance of plants to biotic and abiotic stresses. Soil Sci. Plant Nutr. 2004, 50, 11-18. [CrossRef]

10. Miyake, Y.; Takahashi, E. Silicon deficiency of tomato plant. Soil Sci. Plant Nutr. 1978, 24, 175-189. [CrossRef]

11. Miyake, Y.; Takahashi, E. Effect of silicon on the growth of soybean plants in a solution culture. Soil Sci. Plant Nutr. 1985, 31, 625-636. [CrossRef]

12. Miyake, Y.; Takahashi, E. Effect of silicon on the growth and fruit production of strawberry plants in a solution culture. Soil Sci. Plant Nutr. 1986, 32, 321-326. [CrossRef]

13. Ma, J.F.; Takahashi, E. Effect of silicic acid on phosphorus uptake by rice plant. Soil Sci. Plant Nutr. 1989, 35, 227-234. [CrossRef]

14. Ma, J.F.; Takahashi, E. Effect of silicon on the growth and phosphorus uptake of rice. Plant Soil 1990, 126, 115-119. [CrossRef]

15. Marschner, H.; Oberle, H.; Cakmak, I.; Römheld, V. Growth enhancement by silicon in cucumber (Cucumis sativus) plants depends on imbalance in phosphorus and zinc supply. Plant Soil 1990, 124, 211-219. [CrossRef]

16. Hu, A.Y.; Che, J.; Shao, J.F.; Yokosho, K.; Zhao, X.Q.; Shen, R.F.; Ma, J.F. Silicon accumulated in the shoots results in downregulation of phosphorus transporter gene expression and decrease of phosphorus uptake in rice. Plant Soil 2018, 423, 317-325. [CrossRef]

17. Zhang, Y.; Liang, Y.; Zhao, X.; Jin, X.; Hou, L.; Shi, Y.; Ahammed, G.J. Silicon compensates phosphorus deficit-induced growth inhibition by improving photosynthetic capacity, antioxidant potential, and nutrient homeostasis in tomato. Agronomy 2019, 9, 733. [CrossRef]

18. Fisher, R. A preliminary note on the effect of sodium silicate in increasing the yield of barley. J. Agric. Sci. 1929, 19, 132-139. [CrossRef]

19. Ma, J.F.; Takahashi, E. The effect of silicic acid on rice in a P-deficient soil. Plant Soil 1990, 126, 121-125. [CrossRef]

20. Ma, J.F.; Takahashi, E. Effect of silicate on phosphate availability for rice in a P-deficient soil. Plant Soil 1991, 133, 151-155. [CrossRef]

21. Owino-Gerroh, C.; Gascho, G. Effect of silicon on low pH soil phosphorus sorption and on uptake and growth of maize. Commun. Soil Sci. Plant Anal. 2005, 35, 2369-2378. [CrossRef]

22. Pati, S.; Pal, B.; Badole, S.; Hazra, G.C.; Mandal, B. Effect of silicon fertilization on growth, yield, and nutrient uptake of rice. Commun. Soil Sci. Plant Anal. 2016, 47, 284-290. [CrossRef]

23. Agostinho, F.B.; Tubana, B.S.; Martins, M.S.; Datnoff, L.E. Effect of different silicon sources on yield and silicon uptake of rice grown under varying phosphorus rates. Plants 2017, 6, 35. [CrossRef] [PubMed]

24. Kostic, L.; Nikolic, N.; Bosnic, D.; Samardzic, J.; Nikolic, M. Silicon increases phosphorus (P) uptake by wheat under low P acid soil conditions. Plant Soil 2017, 419,447-455. [CrossRef]

25. Soratto, R.P.; Fernandes, A.M.; Pilon, C.; Souza, M.R. Phosphorus and silicon effects on growth, yield, and phosphorus forms in potato plants. J. Plant Nutr. 2019, 42, 218-233. [CrossRef]

26. Chen, C.H.; Lewin, J. Silicon as a nutrient element for Equisetum arvense. Can. J. Bot. 1969, 47, 125-131. [CrossRef]

27. Ma, J.F.; Miyake, Y.; Takahashi, E. Silicon as a beneficial element for crop plants. Stud. Plant Sci. 2001, 8, 17-39. [CrossRef]

28. Raven, J.A. Silicon transport at the cell and tissue level. In Silicon in Agriculture, 1st ed.; Datnoff, L.E., Korndörfer, G.H., Snyder, G.H., Eds.; Elsevier: Amsterdam, The Netherlands, 2001; pp. 41-55.

29. Tamai, K.; Ma, J.F. Characterization of silicon uptake by rice roots. New Phytol. 2003, 158, 431-436. [CrossRef]

30. Mitani, N.; Ma, J.F. Uptake system of silicon in different plant species. J. Exp. Bot. 2005, 56, 1255-1261. [CrossRef]

31. Nikolic, M.; Nikolic, N.; Liang, Y.; Kirkby, E.A.; Römheld, V. Germanium-68 as an adequate tracer for silicon transport in plants. Characterization of silicon uptake in different crop species. Plant Physiol. 2007, 143, 495-503. [CrossRef]

32. Ma, J.F.; Tamai, K.; Yamaji, N.; Mitani, N.; Konishi, S.; Katsuhara, M.; Ishiguro, M.; Murata, Y.; Yano, M. A silicon transporter in rice. Nature 2006, 440, 688-691. [CrossRef] [PubMed]

33. Ma, J.F.; Yamaji, N.; Mitani, N.; Tamai, K.; Konishi, S.; Fujiwara, T.; Katsuhara, M.; Yano, M. An efflux transporter of silicon in rice. Nature 2007, 448, 209-212. [CrossRef] [PubMed]

34. Sakurai, G.; Satake, A.; Yamaji, N.; Mitani-Ueno, N.; Yokozawa, M.; Feugier, F.G.; Ma, J.F. In silico simulation modeling reveals the importance of the Casparian strip for efficient silicon uptake in rice roots. Plant Cell Physiol. 2015, 56, 631-639. [CrossRef] [PubMed]

35. Yamaji, N.; Sakurai, G.; Mitani-Ueno, N.; Ma, J.F. Orchestration of three transporters and distinct vascular structures in node for intervascular transfer of silicon in rice. Proc. Natl. Acad. Sci. USA 2015, 112, 11401-11406. [CrossRef]

36. Yamaji, N.; Mitatni, N.; Ma, J.F. A transporter regulating silicon distribution in rice shoots. Plant Cell 2008, 20, 1381-1389. [CrossRef] 
37. Yamaji, N.; Ma, J.F. A transporter at the node responsible for intervascular transfer of silicon in rice. Plant Cell 2009, 21, 2878-2883. [CrossRef]

38. Mitani, N.; Yamaji, N.; Ma, J.F. Identification of maize silicon influx transporters. Plant Cell Physiol. 2009, 50, 5-12. [CrossRef]

39. Mitani, N.; Chiba, Y.; Yamaji, N.; Ma, J.F. Identification and characterization of maize and barley Lsi2-like silicon efflux transporters reveals a distinct silicon uptake system from that in rice. Plant Cell 2009, 21, 2133-2142. [CrossRef]

40. Chiba, Y.; Mitani, N.; Yamaji, N.; Ma, J.F. HvLsi1 is a silicon influx transporter in barley. Plant J. 2009, 57, 810-818. [CrossRef]

41. Yamaji, N.; Chiba, Y.; Mitani-Ueno, N.; Ma, J.F. Functional characterization of a silicon transporter gene implicated in silicon distribution in barley. Plant Physiol. 2012, 160, 1491-1497. [CrossRef]

42. Mitani-Ueno, N.; Yamaji, N.; Ma, J.F. Silicon efflux transporters isolated from two pumpkin cultivars contrasting in Si uptake. Plant Signal. Behav. 2011, 6, 991-994. [CrossRef] [PubMed]

43. Mitani, N.; Yamaji, N.; Ago, Y.; Iwasaki, K.; Ma, J.F. Isolation and functional characterization of an influx silicon transporter in two pumpkin cultivars contrasting in silicon accumulation. Plant J. 2011, 66, 231-240. [CrossRef]

44. Sun, H.; Guo, J.; Duan, Y.; Zhang, T.; Huo, H.; Gong, H. Isolation and functional characterization of CsLsi1, a silicon transporter gene in Cucumis sativus. Physiol. Plant. 2017, 159, 201-214. [CrossRef] [PubMed]

45. Sun, H.; Duan, Y.; Qi, X.; Zhang, L.; Huo, H.; Gong, H. Isolation and functional characterization of CsLsi2, a cucumber silicon efflux transporter gene. Ann. Bot. 2018, 122, 641-648. [CrossRef] [PubMed]

46. Sun, H.; Duan, Y.; Mitani-Ueno, N.; Che, J.; Jia, J.; Liu, J.; Guo, J.; Ma, J.F.; Gong, H. Tomato roots have a functional silicon influx transporter but not a functional silicon efflux transporter. Plant Cell Environ. 2020, 43, 732-744. [CrossRef] [PubMed]

47. Vivancos, J.; Deshmukh, R.; Grégoire, C.; Rémus-Borel, W.; Belzile, F.; Bélanger, R.R. Identification and characterization of silicon efflux transporters in horsetail (Equisetum arvense). J. Plant Physiol. 2016, 200, 82-89. [CrossRef] [PubMed]

48. Kamerlin, S.C.; Sharma, P.K.; Prasad, R.B.; Warshel, A. Why nature really chose phosphate. Q. Rev. Biophys. 2013, 46, 1-132. [CrossRef]

49. Schachtman, D.P.; Reid, R.J.; Ayling, S.M. Phosphorus uptake by plants: From soil to cell. Plant Physiol. 1998, 116, 447-453. [CrossRef]

50. MacDonald, G.K.; Bennett, E.M.; Potter, P.A.; Ramankutty, N. Agronomic phosphorus imbalances across the world's croplands. Proc. Natl. Acad. Sci. USA 2011, 108, 3086-3091. [CrossRef]

51. Cordell, D.; White, S. Tracking phosphorus security: Indicators of phosphorus vulnerability in the global food system. Food Secur. 2015, 7, 337-350. [CrossRef]

52. Cordell, D.; Drangert, J.O.; White, S. The story of phosphorus: Global food security and food for thought. Glob. Environ. Chang. 2009, 19, 292-305. [CrossRef]

53. Mudge, S.R.; Rae, A.L.; Diatloff, E.; Smith, F.W. Expression analysis suggests novel roles for members of the Pht1 family of phosphate transporters in Arabidopsis. Plant J. 2002, 31, 341-353. [CrossRef] [PubMed]

54. Rausch, C.; Bucher, M. Molecular mechanisms of phosphate transport in plants. Planta 2002, 216, 23-37. [CrossRef] [PubMed]

55. Liu, F.; Xu, Y.; Jiang, H.; Jiang, C.; Du, Y.; Gong, C.; Wang, W.; Zhu, S.; Han, G.; Cheng, B. Systematic identification, evolution and expression analysis of the Zea mays PHT1 gene family reveals several new members involved in root colonization by arbuscular mycorrhizal fungi. Int. J. Mol. Sci. 2016, 17, 930. [CrossRef]

56. Młodzińska, E.; Zboińska, M. Phosphate uptake and allocation-A closer look at Arabidopsis thaliana L. and Oryza sativa L. Front. Plant Sci. 2016, 7, 1198. [CrossRef]

57. Roch, G.V.; Maharajan, T.; Ceasar, S.A.; Ignacimuthu, S. The role of PHT1 family transporters in the acquisition and redistribution of phosphorus in plants. Crit. Rev. Plant Sci. 2019, 38, 171-198. [CrossRef]

58. Nagy, R.; Vasconcelos, M.; Zhao, S.; McElver, J.; Bruce, W.; Amrhein, N.; Raghothama, K.; Bucher, M. Differential regulation of five Pht1 phosphate transporters from maize (Zea mays L.). Plant Biol. 2006, 8, 186-197. [CrossRef]

59. Ai, P.; Sun, S.; Zhao, J.; Fan, X.; Xin, W.; Guo, Q.; Yu, L.; Shen, Q.; Wu, P.; Miller, A.J. Two rice phosphate transporters, OsPht1;2 and OsPht1;6, have different functions and kinetic properties in uptake and translocation. Plant J. 2009, 57, 798-809. [CrossRef]

60. Chang, M.X.; Gu, M.; Xia, Y.W.; Dai, X.L.; Dai, C.R.; Zhang, J.; Wang, S.C.; Qu, H.Y.; Yamaji, N.; Ma, J.F. OsPHT1;3 mediates uptake, translocation, and remobilization of phosphate under extremely low phosphate regimes. Plant Physiol. 2019, 179, 656-670. [CrossRef]

61. Su, T.; Xu, Q.; Zhang, F.C.; Chen, Y.; Li, L.Q.; Wu, W.H.; Chen, Y.F. WRKY42 modulates phosphate homeostasis through regulating phosphate translocation and acquisition in Arabidopsis. Plant Physiol. 2015, 167, 1579-1591. [CrossRef]

62. Zhou, J.; Jiao, F.; Wu, Z.; Li, Y.; Wang, X.; He, X.; Zhong, W.; Wu, P. OsPHR2 is involved in phosphate-starvation signaling and excessive phosphate accumulation in shoots of plants. Plant Physiol. 2008, 146, 1673-1686. [CrossRef]

63. Wang, J.; Sun, J.; Miao, J.; Guo, J.; Shi, Z.; He, M.; Chen, Y.; Zhao, X.; Li, B.; Han, F. A phosphate starvation response regulator Ta-PHR1 is involved in phosphate signalling and increases grain yield in wheat. Ann. Bot. 2013, 111, 1139-1153. [CrossRef]

64. Devaiah, B.N.; Karthikeyan, A.S.; Raghothama, K.G. WRKY75 transcription factor is a modulator of phosphate acquisition and root development in Arabidopsis. Plant Physiol. 2007, 143, 1789-1801. [CrossRef] [PubMed]

65. Wang, H.; Xu, Q.; Kong, Y.H.; Chen, Y.; Duan, J.Y.; Wu, W.H.; Chen, Y.F. Arabidopsis WRKY45 transcription factor activates PHOSPHATE TRANSPORTER1;1 expression in response to phosphate starvation. Plant Physiol. 2014, 164, 2020-2029. [CrossRef] [PubMed] 
66. Yang, S.Y.; Grønlund, M.; Jakobsen, I.; Grotemeyer, M.S.; Rentsch, D.; Miyao, A.; Hirochika, H.; Kumar, C.S.; Sundaresan, V.; Salamin, N. Nonredundant regulation of rice arbuscular mycorrhizal symbiosis by two members of the PHOSPHATE TRANSPORTER1 gene family. Plant Cell 2012, 24, 4236-4251. [CrossRef] [PubMed]

67. Duan, J.; Tian, H.; Drijber, R.A.; Gao, Y. Systemic and local regulation of phosphate and nitrogen transporter genes by arbuscular mycorrhizal fungi in roots of winter wheat (Triticum aestivum L.). Plant Physiol. Biochem. 2015, 96, 199-208. [CrossRef] [PubMed]

68. Chen, J.; Liu, Y.; Ni, J.; Wang, Y.; Bai, Y.; Shi, J.; Gan, J.; Wu, Z.; Wu, P. OsPHF1 regulates the plasma membrane localization of low- and high-affinity inorganic phosphate transporters and determines inorganic phosphate uptake and translocation in rice. Plant Physiol. 2011, 157, 269-278. [CrossRef] [PubMed]

69. Bayle, V.; Arrighi, J.F.; Creff, A.; Nespoulous, C.; Vialaret, J.; Rossignol, M.; Gonzalez, E.; Paz-Ares, J.; Nussaume, L. Arabidopsis thaliana high-affinity phosphate transporters exhibit multiple levels of posttranslational regulation. Plant Cell 2011, 23, 1523-1535. [CrossRef] [PubMed]

70. Bari, R.; Pant, B.D.; Stitt, M.; Scheible, W.R. PHO2, microRNA399, and PHR1 define a phosphate-signaling pathway in plants. Plant Physiol. 2006, 141, 988-999. [CrossRef]

71. Huang, T.K.; Han, C.L.; Lin, S.I.; Chen, Y.J.; Tsai, Y.C.; Chen, Y.R.; Chen, J.W.; Lin, W.Y.; Chen, P.M.; Liu, T.Y. Identification of downstream components of ubiquitin-conjugating enzyme PHOSPHATE2 by quantitative membrane proteomics in Arabidopsis roots. Plant Cell 2013, 25, 4044-4060. [CrossRef]

72. Chen, J.; Wang, Y.; Wang, F.; Yang, J.; Gao, M.; Li, C.; Liu, Y.; Liu, Y.; Yamaji, N.; Ma, J.F. The rice CK2 kinase regulates trafficking of phosphate transporters in response to phosphate levels. Plant Cell 2015, 27, 711-723. [CrossRef] [PubMed]

73. Duan, K.; Yi, K.; Dang, L.; Huang, H.; Wu, W.; Wu, P. Characterization of a sub-family of Arabidopsis genes with the SPX domain reveals their diverse functions in plant tolerance to phosphorus starvation. Plant J. 2008, 54, 965-975. [CrossRef] [PubMed]

74. Lin, W.Y.; Huang, T.K.; Chiou, T.J. NITROGEN LIMITATION ADAPTATION, a target of microRNA827, mediates degradation of plasma membrane-localized phosphate transporters to maintain phosphate homeostasis in Arabidopsis. Plant Cell 2013, 25, 4061-4074. [CrossRef] [PubMed]

75. Shen, C.; Wang, S.; Zhang, S.; Xu, Y.; Qian, Q.; Qi, Y.; Jiang, D.A. OsARF16, a transcription factor, is required for auxin and phosphate starvation response in rice (Oryza sativa L.). Plant Cell Environ. 2013, 36, 607-620. [CrossRef] [PubMed]

76. Chapin, L.J.; Jones, M.L. Ethylene regulates phosphorus remobilization and expression of a phosphate transporter (PhPT1) during petunia corolla senescence. J. Exp. Bot. 2009, 60, 2179-2190. [CrossRef]

77. Franco-Zorrilla, J.M.; Martin, A.C.; Solano, R.; Rubio, V.; Leyva, A.; Paz-Ares, J. Mutations at CRE1 impair cytokinin-induced repression of phosphate starvation responses in Arabidopsis. Plant J. 2002, 32, 353-360. [CrossRef]

78. Wang, S.; Zhang, S.; Sun, C.; Xu, Y.; Chen, Y.; Yu, C.; Qian, Q.; Jiang, D.A.; Qi, Y. Auxin response factor (OsARF12), a novel regulator for phosphate homeostasis in rice (Oryza sativa). New Phytol. 2014, 201, 91-103. [CrossRef]

79. Versaw, W.K.; Harrison, M.J. A chloroplast phosphate transporter, PHT2;1, influences allocation of phosphate within the plant and phosphate-starvation responses. Plant Cell 2002, 14, 1751-1766. [CrossRef]

80. Rausch, C.; Zimmermann, P.; Amrhein, N.; Bucher, M. Expression analysis suggests novel roles for the plastidic phosphate transporter Pht2;1 in auto- and heterotrophic tissues in potato and Arabidopsis. Plant J. 2004, 39, 13-28. [CrossRef]

81. Guo, B.; Jin, Y.; Wussler, C.; Blancaflor, E.B.; Motes, C.M.; Versaw, W.K. Functional analysis of the Arabidopsis PHT4 family of intracellular phosphate transporters. New Phytol. 2008, 177, 889-898. [CrossRef]

82. Liu, T.Y.; Huang, T.K.; Yang, S.Y.; Hong, Y.T.; Huang, S.M.; Wang, F.N.; Chiang, S.F.; Tsai, S.Y.; Lu, W.C.; Chiou, T.J. Identification of plant vacuolar transporters mediating phosphate storage. Nat. Commun. 2016, 7, 1-11. [CrossRef] [PubMed]

83. Zhao, L.; Versaw, W.K.; Liu, J.; Harrison, M.J. A phosphate transporter from Medicago truncatula is expressed in the photosynthetic tissues of the plant and located in the chloroplast envelope. New Phytol. 2003, 157, 291-302. [CrossRef]

84. Takabatake, R.; Hata, S.; Taniguchi, M.; Kouchi, H.; Sugiyama, T.; Izui, K. Isolation and characterization of cDNAs encoding mitochondrial phosphate transporters in soybean, maize, rice, and Arabidopsis. Plant Mol. Biol. 1999, 40, 479-486. [CrossRef] [PubMed]

85. Shukla, V.; Kaur, M.; Aggarwal, S.; Bhati, K.K.; Kaur, J.; Mantri, S.; Pandey, A.K. Tissue specific transcript profiling of wheat phosphate transporter genes and its association with phosphate allocation in grains. Sci. Rep. 2016, 6, 1-12. [CrossRef] [PubMed]

86. Hassler, S.; Lemke, L.; Jung, B.; Möhlmann, T.; Krüger, F.; Schumacher, K.; Espen, L.; Martinoia, E.; Neuhaus, H.E. Lack of the Golgi phosphate transporter PHT4;6 causes strong developmental defects, constitutively activated disease resistance mechanisms and altered intracellular phosphate compartmentation in Arabidopsis. Plant J. 2012, 72, 732-744. [CrossRef]

87. Irigoyen, S.; Karlsson, P.M.; Kuruvilla, J.; Spetea, C.; Versaw, W.K. The sink-specific plastidic phosphate transporter PHT4;2 influences starch accumulation and leaf size in Arabidopsis. Plant Physiol. 2011, 157, 1765-1777. [CrossRef]

88. Miyaji, T.; Kuromori, T.; Takeuchi, Y.; Yamaji, N.; Yokosho, K.; Shimazawa, A.; Sugimoto, E.; Omote, H.; Ma, J.F.; Shinozaki, K. AtPHT4;4 is a chloroplast-localized ascorbate transporter in Arabidopsis. Nat. Commun. 2015, 6, 1-11. [CrossRef]

89. Wang, G.Y.; Shi, J.L.; Ng, G.; Battle, S.L.; Zhang, C.; Lu, H. Circadian clock-regulated phosphate transporter PHT4;1 plays an important role in Arabidopsis defense. Mol. Plant 2011, 4, 516-526. [CrossRef]

90. Cubero, B.; Nakagawa, Y.; Jiang, X.Y.; Miura, K.J.; Li, F.; Raghothama, K.G.; Bressan, R.A.; Hasegawa, P.M.; Pardo, J.M. The phosphate transporter PHT4;6 is a determinant of salt tolerance that is localized to the Golgi apparatus of Arabidopsis. Mol. Plant 2009, 2, 535-552. [CrossRef] 
91. Wang, C.; Yue, W.; Ying, Y.; Wang, S.; Secco, D.; Liu, Y.; Whelan, J.; Tyerman, S.D.; Shou, H. Rice SPX-Major Facility Superfamily3, a vacuolar phosphate efflux transporter, is involved in maintaining phosphate homeostasis in rice. Plant Physiol. 2015, 169, 2822-2831. [CrossRef]

92. Yang, X.; Post, W.M. Phosphorus transformations as a function of pedogenesis: A synthesis of soil phosphorus data using Hedley fractionation method. Biogeosciences 2011, 8, 2907-2916. [CrossRef]

93. Yang, X.; Post, W.M.; Thornton, P.E.; Jain, A. The distribution of soil phosphorus for global biogeochemical modeling. Biogeosciences 2013, 10, 2525-2537. [CrossRef]

94. Schaller, J.; Faucherre, S.; Joss, H.; Obst, M.; Goeckede, M.; Planer-Friedrich, B.; Peiffer, S.; Gilfedder, B.; Elberling, B. Silicon increases the phosphorus availability of Arctic soils. Sci. Rep. 2019, 9, 1-11. [CrossRef] [PubMed]

95. Schaller, J.; Frei, S.; Rohn, L.; Gilfedder, B.S. Amorphous silica controls water storage capacity and phosphorus mobility in soils. Front. Environ. Sci. 2020, 8, 94. [CrossRef]

96. Obihara, C.; Russell, E. Specific adsorption of silicate and phosphate by soils. J. Soil Sci. 1972, 23, 105-117. [CrossRef]

97. Brown, T.; Mahler, R. Effects of phosphorus and acidity on levels of silica extracted from a Palouse silt loam. Soil Sci. Soc. Am. J. 1987, 51, 674-677. [CrossRef]

98. Pardo, M.; Guadalix, M. Phosphate sorption in allophanic soils and release of sulphate, silicate and hydroxyl. J. Soil Sci. 1990, 41, 607-612. [CrossRef]

99. Lee, Y.B.; Kim, P.J. Reduction of phosphate adsorption by ion competition with silicate in soil. Korean J. Environ. Agric. 2007, 26, 286-296. [CrossRef]

100. Reithmaier, G.M.S.; Knorr, K.H.; Arnhold, S.; Planer-Friedrich, B.; Schaller, J. Enhanced silicon availability leads to increased methane production, nutrient and toxicant mobility in peatlands. Sci. Rep. 2017, 7, 8728. [CrossRef]

101. Hömberg, A.; Obst, M.; Knorr, K.H.; Kalbitz, K.; Schaller, J. Increased silicon concentration in fen peat leads to a release of iron and phosphate and changes in the composition of dissolved organic matter. Geoderma 2020, 374, 114422. [CrossRef]

102. Neu, S.; Schaller, J.; Dudel, G.D. Silicon availability modifies nutrient use efficiency and content, C:N:P stoichiometry, and productivity of winter wheat (Triticum aestivum L.). Sci. Rep. 2017, 7, 1-8. [CrossRef] [PubMed]

103. Dietzel, M. Dissolution of silicates and the stability of polysilicic acid. Geochim. Cosmochim. Acta 2000, 64, 3275-3281. [CrossRef]

104. Ma, J.F.; Takahashi, E. Chapter 7. Function of silicon in plant growth. In Soil, Fertilizer and Plant Silicon Research in Japan, 1st ed.; Elsevier: Amsterdam, The Netherlands, 2002; pp. 151-154.

105. Lee, Y.B.; Hoon, C.; Hwang, J.Y.; Lee, I.B.; Kim, P.J. Enhancement of phosphate desorption by silicate in soils with salt accumulation. Soil Sci. Plant Nutr. 2004, 50, 493-499. [CrossRef]

106. Ryan, P.; Tyerman, S.; Sasaki, T.; Furuichi, T.; Yamamoto, Y.; Zhang, W.; Delhaize, E. The identification of aluminium-resistance genes provides opportunities for enhancing crop production on acid soils. J. Exp. Bot. 2011, 62, 9-20. [CrossRef] [PubMed]

107. Zhao, X.Q.; Shen, R.F. Aluminum-nitrogen interactions in the soil-plant system. Front. Plant Sci. 2018, 9, 807. [CrossRef] [PubMed]

108. Penn, C.J.; Camberato, J.J. A critical review on soil chemical processes that control how soil $\mathrm{pH}$ affects phosphorus availability to plants. Agriculture 2019, 9, 120. [CrossRef]

109. Chen, Z.C.; Liao, H. Organic acid anions: An effective defensive weapon for plants against aluminum toxicity and phosphorus deficiency in acidic soils. J. Genet. Genom. 2016, 43, 631-638. [CrossRef]

110. Che, J.; Yamaji, N.; Shao, J.F.; Ma, J.F.; Shen, R.F. Silicon decreases both uptake and root-to-shoot translocation of manganese in rice. J. Exp. Bot. 2016, 67, 1535-1544. [CrossRef]

111. Liang, L.; Zhao, X.; Yi, X.; Chen, Z.; Dong, X.; Chen, R.; Shen, R. Excessive application of nitrogen and phosphorus fertilizers induces soil acidification and phosphorus enrichment during vegetable production in Yangtze River Delta, China. Soil Use Manag. 2013, 29, 161-168. [CrossRef]

112. Liu, J.L.; Liao, W.H.; Zhang, Z.X.; Zhang, H.T.; Wang, X.J.; Meng, N. Effect of phopshate fertilizer and manure on crop yield, soil $P$ accumulation, and the environmental risk assessment. Agric. Sci. China 2007, 6, 1107-1114. [CrossRef]

113. Zhang, Y.C.; Li, R.N.; Wang, L.Y.; Zhai, C.X.; Chen, L.L.; Wu, X.P.; Wu, H.J.; Wang, X.B.; Li, Y.K. Threshold of soil Olsen-P in greenhouses for tomatoes and cucumbers. Commun. Soil Sci. Plant Anal. 2010, 41, 2383-2402. [CrossRef]

114. Yan, Z.; Liu, P.; Li, Y.; Ma, L.; Alva, A.; Dou, Z.; Chen, Q.; Zhang, F. Phosphorus in China's intensive vegetable production systems: Overfertilization, soil enrichment, and environmental implications. J. Environ. Qual. 2013, 42, 982-989. [CrossRef] [PubMed]

115. Yoneyama, T. Problems on phosphorus fertility in upland soil; 5. Uptake and metabolism of phosphorus of plant. Agric. Hortic. 1988, 63, 16-20.

116. Ryan, M.H.; McInerney, J.K.; Record, I.R.; Angus, J.F. Zinc bioavailability in wheat grain in relation to phosphorus fertiliser, crop sequence and mycorrhizal fungi. J. Sci. Food Agric. 2008, 88, 1208-1216. [CrossRef]

117. Gao, X.; Flaten, D.N.; Tenuta, M.; Grimmett, M.G.; Gawalko, E.J.; Grant, C.A. Soil solution dynamics and plant uptake of cadmium and zinc by durum wheat following phosphate fertilization. Plant Soil 2011, 338, 423-434. [CrossRef]

118. Zhang, W.; Liu, D.; Li, C.; Cui, Z.; Chen, X.; Russell, Y.; Zou, C. Zinc accumulation and remobilization in winter wheat as affected by phosphorus application. Field Crop. Res. 2015, 184, 155-161. [CrossRef]

119. Imran, M.; Rehim, A.; Sarwar, N.; Hussain, S. Zinc bioavailability in maize grains in response of phosphorous-zinc interaction. J. Plant Nutr. Soil Sci. 2016, 179, 60-66. [CrossRef] 
120. Chen, X.X.; Zhang, W.; Wang, Q.; Liu, Y.M.; Liu, D.Y.; Zou, C.Q. Zinc nutrition of wheat in response to application of phosphorus to a calcareous soil and an acid soil. Plant Soil 2019, 434, 139-150. [CrossRef]

121. Li, M.; Huang, C.; Yang, T.; Drosos, M.; Wang, J.; Kang, X.; Liu, F.; Xi, B.; Hu, Z. Role of plant species and soil phosphorus concentrations in determining phosphorus: Nutrient stoichiometry in leaves and fine roots. Plant Soil 2019, 445, $231-242$. [CrossRef]

122. Cakmak, I.; Marschner, H. Mechanism of phosphorus-induced zinc deficiency in cotton. III. Changes in physiological availability of zinc in plants. Physiol. Plant. 1987, 70, 13-20. [CrossRef]

123. Lux, A.; Luxová, M.; Abe, J.; Tanimoto, E.; Hattori, T.; Inanaga, S. The dynamics of silicon deposition in the sorghum root endodermis. New Phytol. 2003, 158, 437-441. [CrossRef]

124. Cernusak, L.A.; Winter, K.; Turner, B.L. Transpiration modulates phosphorus acquisition in tropical tree seedlings. Tree Physiol. 2011, 31, 878-885. [CrossRef] [PubMed]

125. Ma, J.F.; Tamai, K.; Ichii, M.; Wu, G.F. A rice mutant defective in Si uptake. Plant Physiol. 2002, 130, 2111-2117. [CrossRef] [PubMed]

126. Batten, G. Phosphorus fractions in the grain of diploid, tetraploid, and hexaploid wheat grown with contrasting phosphorus supplies. Cereal Chem. 1986, 63, 384-387.

127. Karlen, D.L.; Flannery, R.L.; Sadler, E.J. Aerial accumulation and partitioning of nutrients by corn. Agron. J. 1988, 80, $232-242$. [CrossRef]

128. Rose, T.; Liu, L.; Wissuwa, M. Improving phosphorus efficiency in cereal crops: Is breeding for reduced grain phosphorus concentration part of the solution? Front. Plant Sci. 2013, 4, 444. [CrossRef]

129. Raboy, V. Approaches and challenges to engineering seed phytate and total phosphorus. Plant Sci. 2009, 177, 281-296. [CrossRef]

130. Yamaji, N.; Takemoto, Y.; Miyaji, T.; Mitani-Ueno, N.; Yoshida, K.T.; Ma, J.F. Reducing phosphorus accumulation in rice grains with an impaired transporter in the node. Nature 2017, 541, 92-95. [CrossRef] 